\title{
Providing Reliable Data? Combining Scientific and Historical Perspectives on Flooding Events in Medieval and Early Modern Nuremberg (1400-1800)
}

\begin{abstract}
Extreme weather events or climate phases and their consequences were a common threat to premodern societies. Detailed analysis of specific periods and societies requires profound knowledge of the political, economic, social, and climatic background. As a consequence, a single discipline can hardly study the interdependency of natural impacts and human and societal reactions adequately. Interdisciplinary approaches are thus essential for a more precise and comprehensive understanding. This paper discusses the relevance of historical research on extreme weather events and climate phases in the medieval and early modern period for the calibration and interpretation of proxy data, which environmental physicists and chemists draw from the 'archives of nature'. Preliminary results of an ongoing research project will show how the close examination of administrative records offers a far more accurate perspective on flooding events in Nuremberg than narrative sources, which have, hitherto, dominated our understanding. These precise findings help the natural sciences to evaluate proxy climate data drawn from the analysis of stalagmites situated in proximity to the Nuremberg area. On the other hand, the natural sciences provide clues from the environmental proxies that help to explain the impact strength of extreme weather events and severe climate phases on society. Additionally, this collaborative case study allows reflection on the advantages and problems of interdisciplinary research in the humanities and the natural sciences.
\end{abstract}

Keywords: interdisciplinary study, climate and society, extreme weather and climate, administrative records, stalagmites, chronicles, imperial city, Nuremberg, water and river management

\section{Introduction}

The Middle Ages were a period of significant societal development and differentiation. From the twelfth century onwards, the number of villages and towns in the Holy Roman Empire grew significantly from about 50 towns to approximately 3000 around

Tobias Kluge, Universität Heidelberg, Institut für Umweltphysik, Im Neuenheimer Feld 229, 69120 Heidelberg, Germany, tkluge@iup.uni-heidelberg.de

Maximilian Schuh, Freie Universität Berlin, Friedrich-Meinecke-Institut, Geschichte des Mittelalters, 14195 Berlin, Germany, maximilian.schuh@web.de

Ә Open Access. (C) 2020 Tobias Kluge and Maximilian Schuh, published by De Gruyter. (c) BY-NC-ND This work is licensed under a Creative Commons Attribution-NonCommercial-NoDerivatives 4.0 International License.

https://doi.org/10.1515/9783110546316-002 
1300 and 4000 in the later Middle Ages. ${ }^{1}$ This development was concomitant with generally strong population growth: in the Holy Roman Empire, for example, the population increased from around 5-6 million around the year 1000 to between 13 and 15 million around $1300 .^{2}$ Smaller towns, like Nördlingen, had about 5000 inhabitants, while contemporary censuses indicate between 20000 and 30000 people lived in the city of Nuremberg during the fifteenth century. ${ }^{3}$ But even as they flourished, these towns were under constant threat from earthquakes, extreme weather events, severe epidemics, or political unrest and war. These exceptional events include, for example, the devastating earthquake at Basel in 1356 and famines in the beginning of the fourteenth century and during the $1430 \mathrm{s.}^{4}$

Whereas in most territories princely rule was the standard, in certain autonomous cities an oligarchic craft or merchant elite was able to take over administrative control in the course of the thirteenth and fourteenth centuries. ${ }^{5}$ In Nuremberg, for example, the decline of imperial and royal power after the Staufen rule was the starting point of a continuously growing legal and economic independence for the city, which was fully developed by the beginning of the sixteenth century. ${ }^{6}$

In this contribution, we focus on the interconnection between societal developments, the governance issues specific to a medieval and early modern Reichsstadt in the Holy Roman Empire situated on a river, and the influence of climatic extremes. The study of this premodern setting is particularly instructive, on the one hand, as it is characterized by the fast development of the city and its society as well as the corresponding production of written documents. On the other hand, the period witnessed a strong increase in the impact of natural disasters and climatic extremes. In addition, a high population in a limited space increased the potential vulnerability of the urban society and thus the impact of the catastrophic events induced by adverse weather conditions. The effects and consequences these events

1 Eberhard Isenmann, Die deutsche Stadt im Mittelalter, 1150-1550. Stadtgestalt, Recht, Verfassung, Stadtregiment, Kirche, Gesellschaft, Wirtschaft, 2nd ed. Vienna, Cologne, Weimar 2014, pp. 39-40.

2 Andreas WEIGEL, Bevölkerungsgeschichte Europas, Vienna, Cologne, Weimar 2012, pp. 68-70.

3 ISENMANN (note 1), pp. 58-61.

4 Gerhard FouQuet / Gabriel ZeILINGER, Katastrophen im Spätmittelalter, Darmstadt 2011, pp. 58-83.

5 IsENMANn (note 1), pp. 295-304.

6 Ernst PITZ, Die Entstehung der Ratsherrschaft in Nürnberg im 13. und 14. Jahrhundert (Schriftenreihe zur bayerischen Landesgeschichte 55), Munich 1956; Michael DIEFENBACHER, Nürnberg, Reichsstadt. Verwaltung, in: Historisches Lexikon Bayerns, online: http://www.historisches-lexikon-bayerns.de/ Lexikon/Nürnberg,_Reichsstadt:_Verwaltung (last accessed 15/05/2019); ID., Nürnberg, Reichsstadt. Politische und soziale Entwicklung, in: Historisches Lexikon Bayerns, online: https://www.histori sches-lexikon-bayerns.de/Lexikon/Nürnberg,_Reichsstadt:_Politische_und_soziale_Entwicklung (last accessed 15/05/2019); Carla MEYER-SCHLENKRICH, The Imperial city - the example of Nuremberg, in: Graham A. Loud / Jochen Schenk / Deutsches Historisches Institut London (eds.), The Origins of the German Principalities, 1100-1350. Essays by German Historians, London, New York 2017, pp. 68-82, here pp. $75-80$. 
had on the city were well documented by the municipal administration and by the sums of money it spent to repair damages caused by flooding and to counter their social consequences.

Environmental and climatic conditions are imprinted in natural archives, as, for example, in speleothems. ${ }^{7}$ Speleothems are carbonates that grow quasi-continuously in caves and record changes in climate and environment in their growth layers. Within the carbonate and its structure various proxies, such as isotopes or trace elements, can be used to infer details of climatic and environmental changes. Of the carbonate proxies, isotopes of oxygen and carbon that reflect changes in temperature and rainfall (oxygen isotopes) or temperature and vegetation (carbon isotopes) are amongst the most important and frequently used. ${ }^{8}$ Elements that are incorporated in the carbonate have proven to be useful in deducing changes in the hydroclimate and mineral growth characteristics. ${ }^{9}$ New developments in radiometric dating methods now allow us to assign relatively precise ages to stalagmite layers with uncertainties on the order of 1-10 years (for ages up to a few millennia) ${ }^{10}$ in the case of the U-Th disequilibrium dating method, and a few decades in the case of radiocarbon (C-14) dating. ${ }^{11}$ With high-resolution methods for isotope and element analyses, which allow us to resolve even seasonal and monthly events, ${ }^{12}$ a comparative assessment of historically-documented occurrences becomes possible.

Whereas the two relevant dating methods evolved rapidly, the interpretation of stalagmite proxy data remains challenging. In spite of its potential, proxy data in speleothems can be influenced by several factors ${ }^{13}$ and thus necessitates a detailed investigation of the actual proxy-environment relationship. For example, carbonate $\delta^{18} \mathrm{O}$ inherits the oxygen isotope signal from the drip water that is typically dominated by rainfall; in addition, it contains a component that is related to the

7 Frank McDeRmotT et al., Isotopes in Speleothems, in: Melanie J. LenG (ed.), Isotopes in Palaeoenvironmental Research, Berlin 2006, pp. 185-225.

8 Ian J. FAIRChILD / Andy BAKER, Speleothem Science. From Process to Past Environments, Chichester 2012, p. 450.

9 Ian J. FAIRCHILD / Pauline C. TREBLE, Trace Elements in Speleothems as Recorders of Environmental Change, in: Quaternary Science Reviews 28(5-6) (2009), pp. 449-468.

10 Hai CHENG et al., Improvements in ${ }^{230} \mathrm{Th}$ dating, ${ }^{230} \mathrm{Th}$ and ${ }^{234} \mathrm{U}$ Half-Life Values, and U-Th Isotopic Measurements by Multi-Collector Inductively Coupled Plasma Mass Spectrometry, in: Earth and Planetary Science Letters 371-372 (2013), pp. 82-91.

11 Quan Hua et al., Robust Chronological Reconstruction for Young Speleothems Using Radiocarbon, in: Quaternary Geochronology 14 (2012), pp. 67-80.

12 David P. MAtTEy et al., Seasonal Microclimate Control of Calcite Fabrics, Stable Isotopes and Trace Elements in Modern Speleothems from St. Michaels Cave, Gibraltar, in: Geological Society, London. Special Publications 336 (2010), pp. 323-344; Pauline C. TREBLE et al., Comparison of High Resolution sub-annual Records of Trace Elements in a Modern (1911-1992) Speleothem with Instrumental Climate Data from Southwest Australia, in: Earth and Planetary Science Letters 216 (2003), pp. 141-153.

13 MCDERMOTT et al. (note 7). 
temperature-dependent fractionation between water and carbonate. Fractionation refers to the preferential enrichment or depletion of isotopes in phase transitions (e. g. the change from liquid to vapour), during transport (for example by diffusion) or related to reaction processes. Furthermore, a reaction-kinetic component can alter the signal and mask both contributions. ${ }^{14}$ The detection of extreme events in speleothems is thus only possible under special conditions: 1) the speleothem grows under a drip site connected to the surface with a flow path that exhibits mean residence times on the order of months or less; this ensures that the signal is not completely averaged to an annual mean but shows some meaningful deviations from longterm signals; 2) the speleothem grows continuously and records all seasons; 3 ) the speleothem is not dominated by erratic kinetic components.

The comparative assessment of the data gathered by the analysis of speleothems with data from historical archives makes it possible to evaluate the extent to which extreme events may be imprinted in stalagmite carbonate. In a positive and quantitative case, the natural speleothem archive may provide neutral background information for the assessment of extreme events in the past; it can be used to evaluate historical documents in this context.

\section{Methods and Study Outline}

In our study, the natural sciences benefit from the specific dating of single weatherinduced flooding events gathered from historical documents. Conversely, proxy data for paleoclimate studies drawn from the analysis of stalagmites allow us to assess the value of written sources. The interdisciplinary approach makes new insights possible in two directions:

- Assessment if and to what extent climatic extremes documented in written sources are visible in selected 'natural archives'.

- Assessment of the value and precision of written documents concerning climatic extremes and their consequences.

Furthermore, in a final synthesis, the societal and administrative response to environmental challenges can be evaluated on the basis of the long-term environmental evolution, provided by the natural sciences component of the study, and the political, economic, and societal evolution, as deduced by scholars working in the humanities.

Our case study is the city of Nuremberg, situated at the river Pegnitz, and its $1200 \mathrm{~km}^{2}$ catchment area. Flooding events in premodern Nuremberg mainly occurred during the last months of winter, February and March (Figure 1), and were caused by

14 Matthew S. LACHNIET, Climatic and Environmental Controls on Speleothem Oxygen Isotope Values, in: Quaternary Science Reviews 28 (2009), pp. 412-432. 
meltwater and ice drift. Structures crossing the river within the city, such as bridges, caught the ice, blocked, and dammed up the water flow, thereby causing flooding of the city.

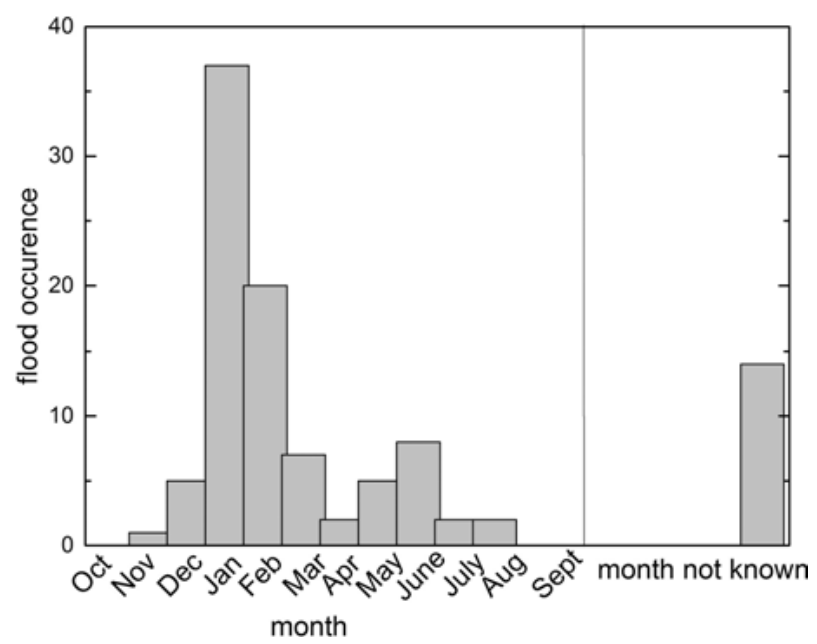

Figure 1: Occurrence of flooding events in Nuremberg $1400-1800$ by month.

Historical research on past climate and weather extremes and their consequences in Nuremberg hitherto focussed mainly on narrative sources such as annals and chronicles. ${ }^{15}$ There are, however, several problems with the analysis of this source type: the sources for these historiographical works are mainly unknown and it is, therefore, difficult to verify the events described. On the other hand, the city chronicles often take a tendentious perspective on events that highlight the actions taken by Nuremberg's ruling elite. Furthermore, early modern chronicles of flooding events seem to stress floods that happened in close temporal proximity to their time of writing. The growing body of administrative writing that was created from the end of the fourteenth century, ${ }^{16}$ in contrast, offers a more contemporary and unbiased perspective on flooding events and other environmental challenges. Records kept by the city's official administration are of high value in this context. For the identification of relevant documents, in-depth knowledge of Nuremberg's structure of administration is thus essential, ${ }^{17}$ starting with the identification of the city's office that dealt with the consequences of flooding. The

15 Rüdiger GLASER et al., Zur Temperatur- und Hochwasserentwicklung der letzten 1000 Jahre in Deutschland, in: DWD Klimastatusbericht 2003 (2004), pp. 55-67, here p. 66.

16 For a comprehensive overview see Paul SANDER, Die reichsstädtische Haushaltung Nürnbergs. Dargestellt auf Grund ihres Zustandes von 1431 bis 1440, Leipzig 1902.

17 Peter Fleischmann, Die Nürnberger Ämterbüchlein, in: Michael DiEFENBACHER / Wiltrud FischeRPACHE (eds.), Das Nürnberger Buchgewerbe. Buch- und Zeitungsdrucker, Verleger und Druckhändler 
most important administrative documents are the 'Ratsverlässe' (“council's decisions”) that shed light on day-to-day business in premodern Nuremberg. Since the end of the fifteenth century, the 'Ratsverlässe' have remained preserved in the municipal archives at Nuremberg. They keep account of the resolutions made by the Innere Rat (the higher administrative council) in its weekly sessions. ${ }^{18}$ A collection of the most important decrees was noted in the 'Ratsbücher' ("council books") and the 'Bürgermeisterbücher' ("mayor's books"). A second important group of documents was created by the city's administrative officers and by commissions that were created in order to solve specific problems within the city. Close examination of the administrative documents allows a relatively unbiased view of flooding events in Nuremberg during the period studied and helps to create an absolute chronology, which can be correlated with data obtained from the analysis of climate proxies.

Close to Nuremberg, well-known and studied caves that contain dated speleothems with up to annual resolution exist in the Jurassic limestone and dolomite of the Fränkische Alb, the 'Franconian Jura'. Annual resolution is provided by visible layers that reflect single years (verified by U-Th and ${ }^{14} \mathrm{C}$ measurements). ${ }^{19}$ For our purposes, it is important that part of the groundwater and river water of the Franconian Jura drains via the Pegnitz that flows through Nuremberg. One cave location that has been investigated in detail is the Zoolithen Cave, approximately $40 \mathrm{~km}$ from Nuremberg. ${ }^{20}$ In the course of an ongoing project (HEiKA "Check Extrema”, funded for 2016 by the Heidelberg University and Karlsruhe Institute of Technology research partnership) new stalagmites have been taken from the Zoolithen Cave and a cave close by, the Kleine Teufelshöhle, in order to close gaps in the data on growth periods of the stalagmites, thereby allowing for a complete comparison of historical documents with the geological archive during the medieval and early modern period. A selection of environmental tracers were analysed in these stalagmites at very high resolution (trace elements such as strontium [Sr] or magnesium $[\mathrm{Mg}]$ and isotopes such as ${ }^{13} \mathrm{C}$ and ${ }^{18} \mathrm{O}$ ) and investigated to determine what they may tell us about climatic extremes. The proxy analysis in the stalagmites has been complemented by a unique high-resolution monitoring of the caves. Physical information (humidity and temperature) together with water drip rates are collected continuously, while water

vom 16. bis zum 18. Jahrhundert (Quellen und Forschungen zur Geschichte und Kultur der Stadt Nürnberg 31), Nuremberg 2003, pp. 560-569.

18 Walter BAUERNFEIND, Innerer Rat, in: Michael DiEFENBACHER / Rudolf ENDRES (eds.), Stadtlexikon Nürnberg, 2nd ed. Nuremberg 2000, p. 477.

19 Dana F. C. Riechelmann et al., Annual-Resolution Carbon and Oxygen Isotope Time Series from Three Stalagmites from Zoolithencave (Southern Germany) and their Potential for Climate Reconstruction, in: Geophysical Research Abstracts 19 (2017), EGU2017-13520.

20 Georg WURTH et al., Der hierarchische Aufbau des Laminationsgefüges eines spät/postglazialen Kerzenstalagmiten aus der Zoolithenhöhle bei Burggaillenreuth (Fränkische Schweiz), in: Detlev K. RICHTER / Georg WURTH (eds.), Beiträge zur Speleologie I (Bochumer Geologische und Geotechnische Arbeiten 55), Bochum 2000, pp. 131-151. 
samples are taken in weekly intervals for isotope and elemental analyses. This kind of high-resolution monitoring has the potential to detect short-term weather-induced variations in the modern proxy data. Modern conditions and related events can serve as an example for past variations and are essential for the interpretation of past proxy data. In addition, the dating of the available and newly taken stalagmites was improved to achieve accuracy with uncertainties on the order of years to decades. For example, three stalagmites of the Zoolithen Cave were dated at the top using ${ }^{14} \mathrm{C}$. The atomic bomb tests of the 1960 s with a unique atmospheric ${ }^{14} \mathrm{C}$ spike provide a precise age marker that allows a good correlation with visible layers and age uncertainties of only a few years. Furthermore, for older growth periods U/Th was measured that provides absolute age tie points with uncertainties on the order of a few decades. Layer counting based on colour changes and fluorescence by humic acid layers (where possible) was applied to suitable stalagmites, which enabled us to adopt an approach that allows a year to year correlation with written documents.

\section{Results}

The study of the period between 1400 and 1800 in this short and focussed research project has already furnished highly interesting insights into climatic extremes, their perception and communication, and the societal responses to them. Of special interest was the assessment of historical documents for their objectivity and the study of stalagmite proxies with regard to potential imprints of extreme climate phases and weather events.

For the city of Nuremberg a 'flood chronology' that covers the period from 1300 to 2000 had already been composed by Rüdiger GLASER and others. ${ }^{21}$ The critical assessment of the existing historical flood chronology for Nuremberg showed that the information used was mainly drawn from the chronicle 'Wassergüß in Nürnberg', written around $1700 .{ }^{22}$ Drawing information only from one source, the chronology's reliability regarding specific details and its comprehensiveness have to be questioned. Many flooding events recorded in the chronicle for the second half of the seventeenth century, for example, were probably common knowledge at the time of its creation or even experienced by the writer himself. On the other hand, no clearly identifiable sources are known for the description of the events from the eleventh to the sixteenth centuries in GLASER's flood chronology. Furthermore, there is no hint as to which sources provide information for flooding events after 1690 in the chronology,

21 Rüdiger GlaSER, Thermische Klimaentwicklung in Mitteleuropa seit dem Jahr 1000, in: Geowisssenschaften 13 (1995), pp. 302-312; ID., Hochwasser, in: DIEFENBACHER / ENDRES (note 18), p. 452; ID. et al. (note 15), p. 66.

22 Nuremberg Staatsarchiv, Rst. Nürnberg, Hs. 434: 'Wassergüß in Nürnberg'. 
when the 'Wassergüß' chronicle ends. As far as the details are concerned, false replication of events, a failure to adjust dates following the introduction of the Gregorian calendar, and the incorrect assignment of dates to events were identified in "tambora. org". ${ }^{23}$ Taken together, these findings cast considerable doubt on the existing flood chronology for Nuremberg.

Our own in-depth historical analysis focussed on the well-known events in 1551, 1595, 1682, 1746, and 1784 that are labelled as 'catastrophic' in current research. These events are not only densely documented in the 'Ratsverlässe' and the records of the various municipal offices, but they also appear in a wide range of additional sources, such as official reports on damage caused by flooding and statutes aiming at preventing future damage and deaths. A detailed study of the available source material shows different intensities in the documentation of the five events. These differences cannot be satisfactorily explained simply by the changes in administrative practices over the centuries. Obviously, the five floods were very different in their extent and had extremely varied impacts on the buildings and the society of Nuremberg. In 1595, for example, it was not only the environmental impact that led to the destruction of the Henkersteg (a bridge inside the city), but inept human reactions played an important role, too: two craftsmen disregarded the orders given by the city official and broke the ice on the river on the wrong side of the Henkersteg. The loose ice then damaged the overpass and led to its collapse. ${ }^{24}$ So it was not only the ice itself that was responsible for this catastrophe, but first and foremost its inadequate handling by the craftsmen. In February 1595, however, the city was flooded twice by the Pegnitz (on the 23rd and the 26th) and the resulting destruction was massive. The council's decrees of the following weeks describe in detail the damaged bridges, mills, and other buildings of the city. ${ }^{25}$ Furthermore,

23 The results of the search with the terms "Hochwasser" and "Nürnberg" in https://www.tam bora.org/ were compared with the original entries in Nuremberg, Staatsarchiv, Rst. Nürnberg, Hs. 434: 'Wassergüß in Nürnberg'.

24 Nuremberg, Staatsarchiv, Rep. 60a, $\mathrm{n}^{\mathrm{o}}$ 1642, fol. $34^{\mathrm{r}-\mathrm{v}}$ (1595 January 18): Uff Meister Petter Carls verordenten waßer grafen, Ansag, was die zween schleuffer bey S. Catharina Closter, als er dieselben Ires uff dem Pegnitz fluß beschehenen Eissens halben, gutlichen zum stilstandt [fol. $\left.34^{\mathrm{V}}\right]$ biß zuvor das Eiß von den untern Mühlen nach einander ledig gemachet und fortt getrieben wurde, vermanet, Ime dagegen fur unnutze böse wortt gegeben, greulich aus gemachet, und mitt schmach wortten uber die Schutt nachgeschrien p., und das sie mitt Irem stettigen Eisen nicht wenig ursecher des erbermblichen schadens bey dem henckerssteg sein möchten $p$.

25 Ibid., $\mathrm{n}^{\mathrm{O}}$ 1643, fol. $40^{\mathrm{r}}$ (1595 February 26): Dieweiln die Schwaben Mühl durch die Itzige grosse wasser gieß sehr grossen schaden gelitten, soll man der aigen frawen, der Erberen Appolonia Sebastian Schleuderspachin, Als zu einem Notpaw, die notturfft Pawholtz geben lassen. Ibid., fol. $49^{\mathrm{r}}$ (1595 March 1): Weilen die waßer Inn dieser Statt noch zimblich groß, unndt die Brucken uber die Pegnitz zum teil gar eingefallen, zum teil sonsten bußwürdig worden, undt also die Jenigen, so über der Pegnitz Jenseits, und herwarts wohnen, schwerlich zusammen kommen können, darauß dann leichtlich ein weittleufftigkeit erfolgen möcht, wann sonnderlich leichtferttiges böses gesindlein sich zusammen rottieren, undt hernach zue früe unvermerckter sachen, sich herein schleichten solt, Alß ist 
they elaborate specific measures taken to respond to the catastrophic events. The main effort was to re-establish the water flow by removing debris from the riverbed with heavy machinery. ${ }^{26}$ Dealing with the economic consequences of the flooding, the focus lay on securing the availability of bread within the city, as the destruction of mills severely hindered the production of flour. ${ }^{27}$ Many more details on the damages and their consequences were noted in the 'Ratsverlässe' of the following weeks. In contrast to the description of the 1595 flood in the 'Wassergüß in Nürnberg' chronicle, that highlights the weather conditions and the flooded area, ${ }^{28}$ we find far more details on the political and societal reactions to the flooding events in the administrative sources.

befolchen die Thor vor dem garaus, undt biß es Tag würdte, biß uff weittern beschaidt, nit zusperren Deßgleichen die strainende Landtsknecht nit herrein Inn die Statt zulasßen, sondern sie der gepür nach abzuweisen.

26 Ibid., $\mathrm{n}^{\circ}$ 1643, fol. $47^{\mathrm{v}}$ (1595 March 1): Die werckhleut, so Inn der feuergehorsam begriffen, soll man alle zu sammen erfordern, undt vonn Inen vernemmen, welcher gestalt durch uffrichtung eines Zugs oder Kränichs die eingefallene Brucken undt Heusser ettlicher maßen auß dem Strom der Pegnitz geraumbt, undt dem Waßer sein freier lauff gemacht werden möchte, damit man uff das ehist wiederumb mahlen könn, waz sie nun also für guett ansehen, das soll man also Inns werckh richten, undt es daneben Inn die verordenten Herren setzen, ob sie Inn mangel gesindts undt Taglöner ettliche Handtwercker uffmahnen losßen wöllen, oder nicht.

27 Ibid., $\mathrm{n}^{\mathrm{o}}$ 1643, fol. $47^{\mathrm{v}}$ (1595 March 1): Dieweil die Yetzo ettlich Tag aneinander geweste große waßergüß ettliche gepeu undt die fürnembsten Mühlwerckh angegriffen, undt zerrisßen, also das man sobalden, undt biß dieselben wieder referiert undt erpauet werden, mit dem mahlen alhie nit würdt vortkommen können, auch dahero albereit mangel undt klemme an brott erfolgt, zu Altorff aber, Neuenmarckht, undt anderer umbgelegener ort die Waßer sich nichts sonnderlichs ergoßen haben sollen.

28 Nuremberg, Staatsarchiv, Rep. 52a, Hs. $\mathrm{n}^{\circ} 434$, fol. $16^{\mathrm{v}}$ : Den 23. February, am St. Matthaiabendt, nachdem es innerhalb vier Wochen, und seit her deß Jüngst geweßenen grosen gewßers und Eyßes, einem großen und tieffen Schnee gelegt, darauff dem gebürg eines Manns hoch war, als dießer nach eingefallen Leim Wetter zerging, kam auff obgemelten tag ein groses und erschröckliches grausames gewäßer alhero, wuchs gegen der Nacht biß umb acht uhr, da stundt es still; biß umb ein gen tag, gieng eine gute Ellen hoch über das Mesene Täffelein gegen dem Sandbadt am Eck der Neuengaßen, rieße zu Wehrd den Langen Steeg ein, wie auch den Steeg auff der Schütt, da die Mühlterstätten ist, mehr stieß es ein stück von der steinern Mauren am St. Catharina Clostergarten ein, gegen der Schütt $z u$, und führet hinweg den Steeg bey der Catharina Schleiffmühl, und den Steeg bey der Pfannenmühl, der Neue Spittal und die Kirchen daselbst, litten große noth, dann das Waßer hette nur noch eine Staffel bevor, das es nicht gar in die Kirchen floß, es gabe sich der Altar bey der Sacristey in der mitt von einander, und wurde das Pflaster in der Kirchen alles auffgehoben, und wurde hernach dieße Kirchen vier Wochen zugespert, die steinerne Parfüßer Brucken, sencket und zerkloh sich, das man solche wegen anlauffung der Leuthe mit Brettern verschlagen muste, es reißet auch eine ganze Seiten Wandt an der Schwabenmühl gegen dem Schleiffersteeg hinweg, in Summa es ist nicht alles zuerzählen, was dießes gewäßer an Heußern, Brucken, Mühlen, un Krämen Gewölbern, umb den Marckt unter deß Rieders Hauß im Spittal, in den Kellern, Badstuben, und den Burigern, so am Waßer gewohnt, am Haiußrath und andern Sachen; für einen unaußsprechlichen Schaden gethan hat, dann sich niemandt eines so großen Waßer beförchtet, und nicht hoch genug auffgeraümet hatte, und 
As a reaction to the regular flooding events and their consequences, several administrative measures were taken in Nuremberg in order to reduce the dangers of the natural hazard. Between 1464 and 1475, for example, Endres Tucher compiled the 'Baumeisterbuch' (“master builder's book”), a manual that collected various preventive measures that could contribute to reducing the flooding risk at neuralgic points in the city, such as the riverbanks, mills, and bridges. Tucher even outlined an emergency action plan in his work. This plan allocates craftsmen with specific skills to specific locations where they could fight the imminent dangers most effectively. Carpenters, for example, were assigned to guard bridges and were to use their tools to destroy sheets of ice that blocked the water flow. Furthermore, an alarm system was installed along the river Pegnitz that helped to anticipate upcoming floods. ${ }^{29}$ According to the account of the contemporary chronicler Sigismund Meisterlin, this organized handling of the environmental impact helped to reduce the damages caused by floods in Nuremberg much more effectively. ${ }^{30}$

From a paleo-climatic perspective, the redaction of the 'Baumeisterbuch' coincided with deteriorating climatic conditions and lower mean annual air temperatures. $^{31}$ Based on the current chronology of the Hölloch stalagmite (Allgäu, Southern Germany) ${ }^{32}$ the climate from 1400-1800 was rather dry (generally high Sr concentration and low Fe concentration) punctuated by a few prominent layers with extremely low Sr concentration (for example, during the sixteenth century). The generally high Sr concentrations coincide with the strongest negative $\delta^{18} \mathrm{O}$ excursion of the last 7000 years in the same stalagmite, which may indicate relatively cold conditions. The flood occurrence chronology including the five investigated

wurde was dießes gewäßer alhier, so einem Erbarn Rath, und gemeinder Burgerschafft Schaden gethan, in drey Thönnen goldtes werth geschäzet.

29 Endres Tucher, Baumeisterbuch der Stadt Nürnberg, 1464-1475, ed. Matthias LEXER, Stuttgart 1862. Cf. Stefanie RÜTHER, Zwischen göttlicher Fügung und herrschaftlicher Verfügung. Katastrophen als Gegenstand spätmittelalterlicher Sicherheitspolitik, in: Christoph KAMPMANN / Ulrich NIGGEMANN (eds.), Sicherheit in der Frühen Neuzeit. Norm, Praxis, Repräsentation, Cologne 2013, pp. 335-350. Contemporary background to LEXER's edition of the 'Baumeisterbuch' is provided by Jürgen PETERSOHN, Geschichtswissenschaft engagiert sich für Germanistik. Franz Xaver Wegele und die Berufung des Kärntners Matthias Lexer an die Universität Würzburg (1868/1869), in: Mitteilungen des Instituts für Österreichische Geschichtsforschung 124 (2016), pp. 430-435.

30 Sigismund Meisterlin's Chronik der Reichsstadt Nürnberg. 1488, in: Karl HEGEL (ed.), Die Chroniken der fränkischen Städte. Nürnberg, vol. 3 (Die Chroniken der Deutschen Städte 3), Leipzig 1864, pp. 1-178, here p. 169: Anno domini 1379 jar. Zu diesen zeiten tet die Pegnitz unaussprechenlichen großen schaden der stat Nurenberg, wann der fluß was nit eingefast, noch mit mauren versorgt, noch mit brucken von felsen gemacht, als nun bei unsern tagen.

31 Michael E. ManN et al., Proxy-Based Reconstructions of Hemispheric and Global Surface Temperature Variations over the Past Two Millennia, in: Proceedings of the National Academy of Sciences 105(36) (2008), pp. 13252-13257.

32 Georg WuRTH et al., The Younger Dryas and Holocene Climate Record of a Stalagmite from Hölloch Cave (Bavarian Alps, Germany), in: Journal of Quaternary Science 19 (2004), pp. 291-298. 
'catastrophic' floods mimic the curve based on $\delta^{18} \mathrm{O}$ (Figure 2). This coincidence could be due to the importance of winter floods and ice blockages for Nuremberg. Thus, an increasing number of days with freezing temperatures may have increased the risk of damage caused by rafting ice; this may consequently have triggered the composition of the 'Baumeisterbuch'.

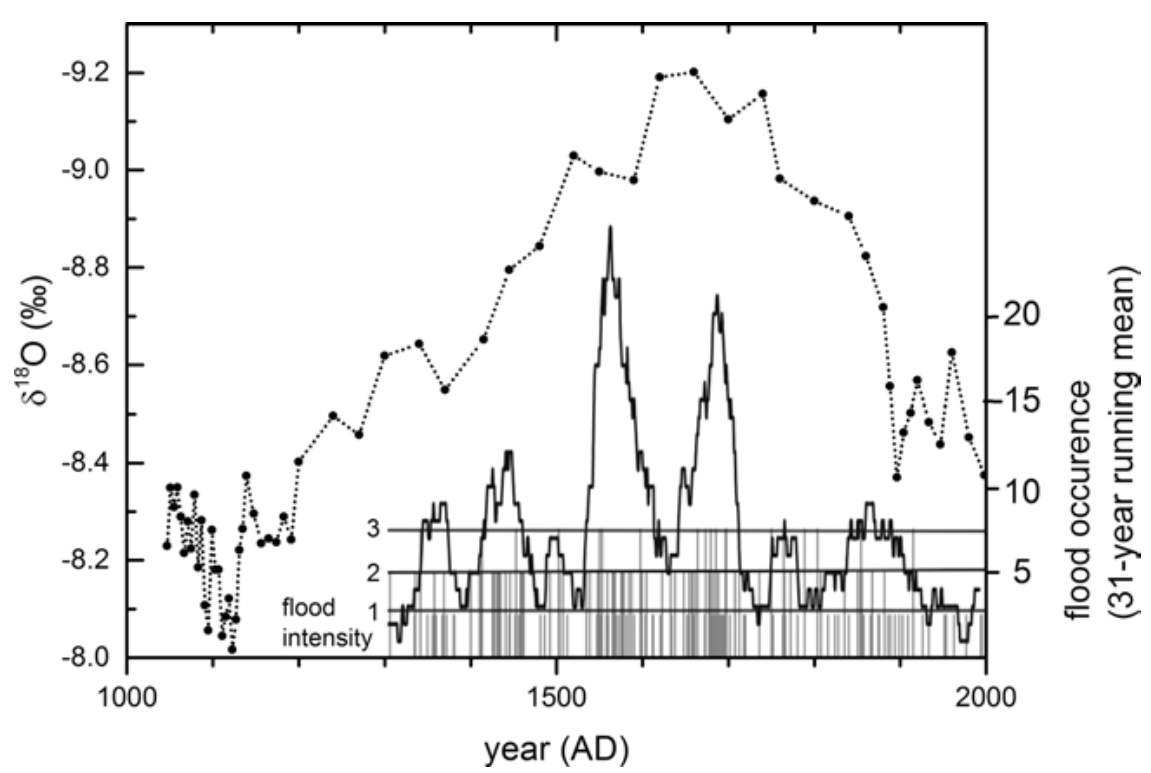

Figure 2: Flood occurrence chronology of Nuremberg (continuous line, right axis; modified from GLASER et al. [note 15], p. 66) relative to the oxygen isotope evolution of the Hölloch stalagmite (dotted line, left axis). Colder periods in this stalagmite are related to more negative $\delta^{18} 0$ values. The stalagmite $\delta^{18} 0$ values were measured and provided by Prof. Dr. Christoph SPÖTL from Innsbruck University.

As repeated references in administrative records and the existence of several copies demonstrate, the 'Baumeisterbuch' was annotated with comments and remained in use in the seventeenth century. ${ }^{33}$ In combination with the inhabitants' legally binding obligation to keep the river free of ice, such precautions apparently helped to improve the situation significantly. By the end of the eighteenth century, and heavily influenced by the experience of the 1784 flood, an ordinance was created and published by the city council that contained clearly defined measures and rules for flood protection. ${ }^{34}$

33 For example, the copy Nuremberg, Stadtarchiv, B 1/I, $n^{\circ} 17$, fol. $209^{\mathrm{v}}-244^{\mathrm{r}}$.

34 Ordnung, wie es allhier zu Nürnberg mit den Anstalten zu Abwendung der Gefahr bei außerordentlicher Ergießung des Pegnizflußes, gehalten werden solle, [Nuremberg] 1785. 
Shortly before the end of the autonomy of the city in 1806, modern forms of state government can be detected. ${ }^{35}$ The constant threat of flooding prompted the city's ruling elite to create and implement effective strategies to reduce the risks and damages caused by these natural hazards. Nevertheless, these actions did not suffice to contain the consequences of the four mentioned major floods, and environmental impacts repeatedly challenged the premodern city society that lived on the river.

\section{Implications and Outlook}

Finally, it is worth asking, how the interdisciplinary study of flooding events in medieval and early modern Nuremberg might be relevant today. On a scientific level, both the natural sciences and the humanities involved in this project benefit from an integrated approach. The project's design is based on mutual understanding of the research methods in each field. This requires intensive and fundamental exchange of the insights that can be gained on both sides. Geoscience and historical research thus have to discuss their ways of creating knowledge. In the course of this discussion, it became clear that both sides are ultimately interpreting information, drawn on the one side from documents and on the other side from stalagmites. In the end, their methods of achieving scientific insights are based on similar groundwork. Once one engages in this process of discussion and exchange, the differences between the natural sciences and the humanities tend to become far less important.

As far as our immediate object is concerned, the historical analysis of the administrative records in Nuremberg allows us to compile a reliable chronology of flooding events in the city during the premodern period. This chronology can, in turn, help the natural sciences to calibrate their climate proxy data drawn from the analysis of stalagmites. As no other similarly reliable data points for calibration exist, cooperation involving historical research entails profound advantages for the geosciences. For historical research, on the other hand, the analysis of the climate proxy data provides an unbiased reconstruction of past climate change and extreme weather events. This reconstruction is not based on human perceptions but on signals in the 'archives of nature'. Although the analysis of the signals also requires interpretation, they provide a completely different perspective on the past than historical documents. This helps to evaluate the perceptions of environmental impacts in the written sources.

35 Helge WeInGÄRTNER, Die Selbstverwaltung der Reichsstadt Nürnberg, in: Michael DiEFENBACHER / Gerhard RECHTER (eds.), Vom Adler zum Löwen. Die Region Nürnberg wird bayerisch 1775-1835 (Ausstellungskataloge des Stadtarchivs Nürnberg 17), Nuremberg 2006, pp. 29-42; DIEFENBACHER, Entwicklung (note 6). 
Reactions to the flooding events in Nuremberg between 1400 and 1800 show that the ruling elite and the population of the city were not helpless victims of the environmental challenges. Already in the fifteenth century the "Baumeister" ("master builder") as city official and his craftsmen identified ice as the main reason for flooding during the winter months and developed adaptive strategies. In consequence, many of the responses to the danger of flooding aimed at destroying ice and preventing it from blocking the water flow of the river. The knowledge and the related expertise were written down in the 'Baumeisterbuch', a work that remained in use until the seventeenth century and formed the basis for later regulations and legislation concerning the river. The recurring environmental challenges for a city situated at a river were met with considered measures that addressed the primary cause of something that might otherwise have potentially fatal consequences.

Overall, an awareness of the environmental challenges and their main dangers is discernible. Out of self-interest, but also out of responsibility for the community, the ruling city elite created a system that helped to tackle the problems that arose from the river. ${ }^{36}$ This system was cultivated and improved over the centuries, although it could not prevent the catastrophic consequences of extreme floods. Nevertheless, its sheer existence attests to a willingness to address the imminent threat on a basis that outlasted the lives of individual persons.

In order to conclude this preliminary report on our research, we would like to highlight that we are facing several institutional problems arising from the interdisciplinary approach we have adopted to the study of flooding events in medieval and early modern Nuremberg. It must be underlined that gathering data from stalagmites in caves and from documents in archives both represent time-consuming activities. Funding for this kind of long-term project that involves complex research for all the participating disciplines is difficult to obtain. Unfortunately, the traditional programmes financed by the German Science Foundation or similar institutions are not designed with collaborative projects that bring together the (natural) sciences and the humanities in mind. As a consequence, we must rely on smaller grants in order to pay for particular aspects of our research. This is an additional obstacle to the execution of an already challenging endeavour. Yet another problem is publishing our results, as we have to identify options that are equally attractive to all the researchers who participate in the project. There is little common ground to be found between academic publications in geosciences and history. Consequently, we have to look for alternative formats. This is a case in point. Being part of this innovative volume on the relevance of the Middle Ages

36 Andrea Bendlage / Peter Schuster, Hüter der Ordnung. Bürger, Rat und Polizei in Nürnberg im 15. und 16. Jahrhundert, in: Mitteilungen des Vereins für Geschichte der Stadt Nürnberg 82 (1995), pp. 37-55. 
allows us to present our research to researchers from the humanities; for an audience from the (natural) sciences we will have to find another forum for publication. The fruitful exchange that enriches our respective work, however, continues to motivate us, all the while enabling us to broaden our perspective in unexpected ways.

Acknowledgment: The HEiKA (Heidelberg-Karlsruhe Research Partnership Heidelberg University, Karlsruhe Institute of Technology (KIT), Germany) Project team "Check Extrema" consisted of Thomas Neumann, Elisabeth Eiche, Philipp Holz, Arno Hartmann (all Institute of Applied Geosciences, KIT), Tobias Kluge (Institute of Environmental Physics, Heidelberg University), Gabriel Meyer, and Maximilian Schuh (Historisches Seminar, Heidelberg University). We acknowledge the joint effort of the whole team for the investigation and assessment of the research topic and are grateful for funding provided by HEiKA. 